\begin{tabular}{|c|c|c|c|c|c|c|c|c|c|c|}
\hline & & & $\begin{array}{c}\text { Model } \\
\text { TA }\end{array}$ & & & & & $\begin{array}{c}\text { Model } \\
4 \mathrm{~A}\end{array}$ & & \\
\hline & AFS & $\mathrm{CS}_{1}$ & $\mathrm{CL}_{1}$ & $\mathrm{CS}_{2}$ & $\mathrm{CL} 2$ & AFS & $\mathrm{CS}_{1}$ & $\mathrm{CL}_{1}$ & $\mathrm{CS}_{2}$ & $\mathrm{CL} 2$ \\
\hline \multicolumn{11}{|l|}{ Fixed Part } \\
\hline Cons & $\begin{array}{c}0.114 \\
{[0.134]}\end{array}$ & $\begin{array}{c}0.253 \\
{[0.174]}\end{array}$ & $\begin{array}{c}0.195 \\
{[0.164]}\end{array}$ & $\begin{array}{c}0.213 \\
{[0.147]}\end{array}$ & $\begin{array}{c}0.375 \\
{[0.213]}\end{array}$ & {$\left[\begin{array}{c}0.371 \\
{[0.169]^{*}}\end{array}\right.$} & $\begin{array}{c}0.245 \\
{[0.174]}\end{array}$ & $\begin{array}{c}0.918 \\
{[0.200]^{*}}\end{array}$ & $\begin{array}{c}0.152 \\
{[0.097]}\end{array}$ & $\begin{array}{c}0.274 \\
{[0.173]}\end{array}$ \\
\hline Slope & $\begin{array}{c}-0.047 \\
{[0.069]}\end{array}$ & $\begin{array}{c}-0.101 \\
{[0.071]}\end{array}$ & $\begin{array}{c}-0.045 \\
{[0.063]}\end{array}$ & $\begin{array}{c}-0.083 \\
{[0.056]}\end{array}$ & \begin{tabular}{|c|}
-0.121 \\
{$[0.091]$}
\end{tabular} & \begin{tabular}{|c}
-0.222 \\
{$[0.088]$}
\end{tabular} & $\begin{array}{c}-0.109 \\
{[0.071]^{*}}\end{array}$ & $\left.\begin{array}{c}0.045 \\
{[0.064]}\end{array}\right]$ & $\begin{array}{c}-0.061 \\
{[0.046]}\end{array}$ & $\begin{array}{l}-0.098 \\
{[0.075]}\end{array}$ \\
\hline \multicolumn{11}{|c|}{ Prior attainment } \\
\hline English & & & & & & $\begin{array}{c}0.056 \\
{[0.012]^{* *}}\end{array}$ & $\begin{array}{c}0.084 \\
{[0.013]^{*}}\end{array}$ & $\begin{array}{c}0.073 \\
{[0.013]^{*}}\end{array}$ & {$\left[\begin{array}{c}0.029 \\
{[0.013]^{*}}\end{array}\right.$} & \begin{tabular}{|l|}
-0.013 \\
{$[0.011]$}
\end{tabular} \\
\hline Maths & & & & & & $\mid \begin{array}{c}0.077 \\
{[0.014]^{*}}\end{array}$ & $\begin{array}{c}0.009 \\
{[0.014]}\end{array}$ & $\mid \begin{array}{c}0.034 \\
{[0.014]^{* *}}\end{array}$ & $\begin{array}{c}0.003 \\
{[0.013]}\end{array}$ & $\begin{array}{c}0.034 \\
{[0.012]}\end{array}$ \\
\hline Science & & & & & & $\begin{array}{c}0.057 \\
{[0.014]^{*}}\end{array}$ & $\begin{array}{c}0.043 \\
{[0.014]^{*}}\end{array}$ & {$\left[\begin{array}{c}0.043 \\
{[0.014]^{* *}}\end{array}\right.$} & $\begin{array}{c}0.027 \\
{[0.014]^{*}}\end{array}$ & $\begin{array}{c}0.010 \\
{[0.012]}\end{array}$ \\
\hline $\mathrm{CS}_{1} / \mathrm{CL}_{1}$ & & & & & & & & & $\begin{array}{c}0.302 \\
{[0.013]^{*}}\end{array}$ & $\begin{array}{c}0.360 \\
{[0.011]}\end{array}$ \\
\hline \multicolumn{11}{|l|}{ Background } \\
\hline Age & & & & & & $\begin{array}{c}-0.001 \\
{[0.005]}\end{array}$ & $\begin{array}{c}-0.018 \\
{[0.005]^{*}}\end{array}$ & $\begin{array}{c}-0.032 \\
{[0.005]^{*}}\end{array}$ & {$\left[\begin{array}{c}-0.012 \\
{[0.005]^{*}}\end{array}\right.$} & $\begin{array}{c}-0.013 \\
{[0.005]}\end{array}$ \\
\hline $\begin{array}{l}\text { Gender } \\
\text { (Male) }\end{array}$ & & & & & & $\mid \begin{array}{c}0.114 \\
{[0.028]^{*}}\end{array}$ & $\begin{array}{c}0.016 \\
{[0.029]}\end{array}$ & $\mid \begin{array}{c}-0.100 \\
{[0.030]^{* *}}\end{array}$ & {$\left[\begin{array}{c}0.021 \\
{[0.029]}\end{array}\right.$} & $\begin{array}{l}-0.042 \\
{[0.026]}\end{array}$ \\
\hline \begin{tabular}{|l} 
Mean \\
English
\end{tabular} & & & & & & $\begin{array}{c}-0.262 \\
{[0.119]^{*}}\end{array}$ & $\begin{array}{c}-0.325 \\
{[0.351]}\end{array}$ & $\begin{array}{c}-0.163 \\
{[0.306]}\end{array}$ & $\begin{array}{c}0.251 \\
{[0.172]}\end{array}$ & $\begin{array}{c}-0.321 \\
{[0.318]}\end{array}$ \\
\hline $\begin{array}{l}\text { Mean } \\
\text { Science }\end{array}$ & & & & & & $\begin{array}{c}-0.115 \\
{[0.324]}\end{array}$ & $\begin{array}{c}0.334 \\
{[0.209]}\end{array}$ & $\begin{array}{c}0.043 \\
{[0.014]^{*}}\end{array}$ & $\begin{array}{c}0.193 \\
{[0.102]}\end{array}$ & $\begin{array}{c}0.004 \\
{[0.189]}\end{array}$ \\
\hline \multicolumn{11}{|c|}{ Random Part (Variances) } \\
\hline \begin{tabular}{|l|} 
Between \\
Tr./Dept. \\
in their \\
intercepts \\
\end{tabular} & $\begin{array}{c}0.251 \\
{[0.102]^{* *}}\end{array}$ & $\begin{array}{c}0.447 \\
{[0.171]^{* *}}\end{array}$ & $\begin{array}{c}0.393 \\
{[0.152]^{*}}\end{array}$ & $\begin{array}{c}0.308 \\
{[0.121]^{* *}}\end{array}$ & $\begin{array}{c}0.689 \\
{[0.256]^{* *}}\end{array}$ & $\begin{array}{c}0.248 \\
{[0.100]^{*}}\end{array}$ & $\begin{array}{c}0.443 \\
{[0.171] *}\end{array}$ & $\begin{array}{c}0.386 \\
{[0.149]^{* *}}\end{array}$ & $\begin{array}{c}0.114 \\
{[0.051]^{* *}}\end{array}$ & $\begin{array}{c}0.442 \\
{[0.167]^{*}}\end{array}$ \\
\hline Slope & $\begin{array}{c}0.066 \\
{[0.027]^{* *}} \\
\end{array}$ & $\begin{array}{c}0.073 \\
{[0.029]^{*}}\end{array}$ & $\begin{array}{c}0.055 \\
{[0.022]} \\
\end{array}$ & $\begin{array}{c}0.043 \\
{[0.011]^{* *}}\end{array}$ & $\begin{array}{c}0.125 \\
{[0.047]^{* *}}\end{array}$ & $\begin{array}{c}0.069 \\
{[0.027]^{* *}}\end{array}$ & $\begin{array}{c}0.072 \\
{[0.028]^{*}}\end{array}$ & $\begin{array}{c}0.057 \\
{[0.027]^{*}}\end{array}$ & $\begin{array}{c}0.027 \\
{[0.021]} \\
\end{array}$ & $\begin{array}{c}0.084 \\
{[0.032]^{*}}\end{array}$ \\
\hline \begin{tabular}{|l|} 
Between \\
students
\end{tabular} & $\begin{array}{c}0.921 \\
{[0.017]^{*}}\end{array}$ & $\begin{array}{c}0.848 \\
{[0.016]^{*}}\end{array}$ & $\begin{array}{c}0.881 \\
{[0.016]^{*}}\end{array}$ & $\begin{array}{c}0.930 \\
{[0.017]^{*}}\end{array}$ & $\begin{array}{c}0.783 \\
{[0.014]^{*}}\end{array}$ & $\begin{array}{c}0.903 \\
{[0.017]^{* *}}\end{array}$ & $\begin{array}{c}0.836 \\
{[0.015]^{* *}}\end{array}$ & $\begin{array}{c}0.864 \\
{[0.016]^{*}}\end{array}$ & $\begin{array}{c}0.847 \\
{[0.016]^{*}}\end{array}$ & $\begin{array}{c}0.665 \\
{[0.012]^{*}}\end{array}$ \\
\hline Total & 1.172 & 1.295 & 1.274 & 1.238 & 1.472 & 1.151 & 1.279 & 1.250 & 0.978 & 1.107 \\
\hline \multicolumn{11}{|c|}{ Variance explained } \\
\hline Tr./Dept. & & & & & & 1 & 1 & 2 & 63 & 36 \\
\hline Student & & & & & & 2 & 1 & 2 & 9 & 15 \\
\hline Total & & & & & & 2 & 1 & 2 & 21 & 25 \\
\hline $\begin{array}{l}\text { \% variance } \\
\text { attributable } \\
\text { to } T r \text { r. dept. }\end{array}$ & 21 & 36 & 31 & 25 & 47 & 22 & 35 & 31 & 12 & 40 \\
\hline
\end{tabular}

Note: * = Statistically significant at .050 significance level.

\section{Is Transition from Secondary to Tertiary Education Less Likely among Black South Africans than their Non-Black Counterparts in the Democratic Dispensation?}

\author{
Nisha Sewdass and Eric O Udjo
}

Abstract

Education provides the building blocks for skills development for a country's labour market. Investment in education is hence an important determinant of economic growth and has been associated with various economic benefits. However, non-transition to tertiary education is a common phenomenon. This study examined the probability of a specified age cohort transiting to tertiary education in South Africa and compared Black South Africans with other population groups considering environmental and individual factors. Using cross-sectional data from the 2016 South African Community Survey, the study revealed that the difference in the probability of transition to tertiary education between Whites and Blacks was not statistically significant. The findings will be useful to policy makers in formulating strategies to improve the quality of the labour market, and thus South Africa's economic competitiveness.

Key words: Transition to tertiary education, South African education system, apartheid education, post-apartheid education, economic development

L'éducation est la base du développement des compétences pour le marché du travail d'un pays. L'investissement dans l'éducation est donc un déterminant important de la croissance économique et a été associé à divers avantages économiques. Toutefois, la difficulté de passage vers le niveau supérieur est un phénomène courant. Cette étude examine la probabilité qu'a une cohorte d'âge spécifiée de passer vers le niveau d'enseignement supérieur en Afrique du Sud et compare le niveau de passage des Sud-Africains noirs avec celui d'autres groupes de population en tenant compte de

ABOUT THE AUTHORS: NISHA SEWDASS, University of South Africa. Email: sewdan@ unisa.ac.za and ERIC O UDJO, University of South Africa. 
facteurs environnementaux et individuels. En utilisant des données transversales de l'enquête de 2016 sur les communautés sud-africaines, l'étude a révélé que la différence dans la probabilité de passage vers l'enseignement supérieur entre les blancs et les noirs n'était pas statistiquement significative. Les conclusions de l'étude seront utiles aux décideurs pour formuler des stratégies visant à améliorer la qualité du marché du travail et, partant, la compétitivité économique de l’Afrique du Sud.

Mots clés: passage vers l'enseignement supérieur, système éducatif sudafricain, éducation à l'apartheid, éducation post-apartheid, développement économique

\section{Introduction}

\section{Background and problem statement}

Labour market intelligence to guide policy in improving a country's economic competitiveness requires knowledge of transition to educational institutions as well as educational attainment in the population. This entails examining the characteristics of students who do not transit to tertiary education as well as the characteristics of those who transit but do not complete such education. This kind of analysis is generally lacking in South Africa. According to Schieferdecker and Riphahn (2012), the determinants of entry to tertiary education are of immediate policy relevance for several reasons. For example, high demand for a qualified labour force directs political attention to broadening access to tertiary education. Raborife (20I7) claimed that for every six White students that transited to university, only one Black student did, with the main reasons being poverty and a lack of adequate support for Black and Coloured children at home. However, empirical evidence in support of this claim is lacking.

A country's economic competitiveness is partly dependent on the quality of its labour market which, in turn, is determined by the skills acquired through formal education at various levels as well as lifetime experiences in different levels of employment. Education is therefore a catalyst that provides the building blocks for skills development for a country's labour market. According to Nelson Mandela (posted in Patterson, 20I3), education is the greatest engine of personal development, no country can really develop unless its citizens are educated, and education is the most powerful weapon which can be used to change the world. Blondal, Field and Girouard (2002) observe that investment in education is an important determinant of economic growth and that education has been found to be associated with various economic benefits. Blondal et al. (2002) add that acquired knowledge and skills tend to raise productivity and hence earning potential. Matkovic and Kogan (2012) also observe that complet- ing tertiary education is associated with a better income, job and quality of work, as well as employment stability and prospects for promotion. Thus, the Organisation for Economic Co-operation and Development (OECD) countries aim to ensure that all young people enter working life with a minimum amount of human capital acquired during the years of compulsory education (Blondal et al., 2002).

In view of the benefits of education, governments all over the world invest in primary, secondary, and tertiary education to varying degrees. However, non-transition to tertiary education is a common phenomenon irrespective of whether it is fully or partially subsidised by the government. Matkovic and Kogan (2012) observed that about $72 \%$ of young adults in OECD countries enter tertiary education in their lifetime, while Vandenberghe (2007) estimated that $58 \%$ of individuals aged I7-24 in Belgium transited to tertiary education after completing secondary school during the period I990-2000. The corresponding percentages in Germany, Hungary, Poland and the United Kingdom (UK) were I4\%, 32\%, I2\% and $27 \%$, respectively. In Hong Kong due to the highly competitive joint university programmes admissions system, less than I $8 \%$ of students that had completed upper secondary education were granted places in higher education in 200I/I (Post 2003). Citing a Global Monitoring Report, Essack (20I2) noted that, in 2009, sub-Saharan Africa had the lowest proportion of the total population of the relevant age cohort enrolled in education at all levels in the world. The weighted average of people accessing tertiary education in sub-Saharan Africa in 2005 was only $5 \%$, with more men than women participating. (Essack, 20I2). Harper (20I2) observed that in 2002, Black men comprised only $4.3 \%$ of students enrolled at higher education institutions in the United States (US).

Weiss and Steininger (20I2) observed that decisions with regard to participation in tertiary education depend on social background such as parental occupational status or education. They also noted that social background influences the timing of entry to higher education. The authors identified four factors that influence non-participation: (a) status maintenance: families are motivated to achieve at least the same social position for their offspring as themselves. Thus, offspring whose parents do not have a high level of education will not participate in higher education; (b) Financial resources: young adults from less wealthy families might not have sufficient resources to finance higher education; (c) Perceived probability of success: Young adults whose parents are in a lower educational category feel that they are at a high risk of failing in higher education and would thus be reluctant to enrol; (d) Lower performance: failure to meet the minimum final secondary grade requirements for entry to higher education. According to Scheiferdecker and Riphann (2OI2), higher parental 
age is known to increase secondary school attainment but should not affect subsequent transition to tertiary education. Salmi and Basset (20I4) observed that while the share of the tertiary education age cohort (I9-25 years) granted the opportunity to study has increased worldwide in the past two decades, disparities in terms of sex, membership of minority populations, disabilities, and academic and financial barriers are still major obstacles to participation.

Non-completion is another challenge in tertiary education. Matkovic and Kogan (20I2) observed that on average, only about $69 \%$ of tertiary education entrants complete their education in OECD countries. O'Koeffe (20I3) found that attrition rates in post-secondary education stood at $30-50 \%$ in the US and $20 \%$ in Australia. Shapiro et al.'s (20I5) study on the outcomes for students who began post-secondary education in 2009 in the US reported that the overall national six-year completion rate was $52.9 \%$. This represented a decline of 2.I percentage points from the 2008 cohort, or twice the rate of decline that was observed in the 2007 cohort compared with the 2008 cohort. Radford, Wheeless and Hunt-White's (2010) survey of a nationally representative sample of about 90 ooo students in the US who enrolled for postsecondary studies for the first time in 2003/4 observed that $3 \mathrm{I} \%$ of the students received a Bachelor's degree within six years, while $35 \%$ had not received a degree and were not enrolled at any institution. Scott (2005) estimated that $40 \%$ of domestic students starting tertiary education in New Zealand in I998 completed after five years, while 51\% left after five years without completing. Of the cohort that started tertiary education in 200 I, $62 \%$ left the following year.

Scott (2005) found that in New Zealand, women were more likely to successfully complete a tertiary qualification than men, while students under the age of 25 had higher completion rates across all levels of study. Shapiro et al.'s (2OI5) study revealed older students and full-time students in the US experienced some of the largest decreases in completion rates. Harper (20I2) noted that only $47 \%$ of Black male students graduated on time from US high schools in 2008 compared to $78 \%$ of White male students. Harper (20I2) also noted that Black male college completion rates were lowest among both sexes and all racial/ethnic groups in the US.

Matkovic and Kogan (2OI2) compared the situations of non-completers and completers of tertiary education. They found that non-completers were worse off in terms of salary, job quality, high levels of unemployment in their early career, and less access to graduate occupations. Non-completers were also observed to experience higher rates of crime (Owens, 2004 cited in Lamb and Markussen, 20II). The literature suggests that, at the macro level, non-completion of tertiary education is a waste of national resources because students' failure to complete programmes (Yorke, I998) increases welfare needs, and results in poor physical and mental health and a reduced tax base (Owens, 2004 cited in Lamb and Markussen, 20II). Non-completion can also affect the funding of tertiary education institutions (Yorke, I998).

Several reasons have been cited for non-completion of tertiary education, including mental health, disability, socioeconomic and ethnic status, a lack of sense of belonging within higher education institutions (O'Koeffe, 20I3), and family income (Vandenberghe, 2007). Harper (2012) observed that Black males' success in higher education in the US was partly attributable to being able to pursue their Bachelor's degree without the burden of financial stress. Harper (20I2) added that these achievers reported having a good start, including bridging programmes that brought them to the institutions before the start of the first year that acquainted them with the environment and the resources available.

Longitudinal cohort data to assess completion rates are not publicly available in South Africa. The exception is Van Broekhuizen, Van Der Berg, and Hofmeyr's (2016) study that focused on six-year outcomes for students who began post-secondary education in 2009. National Senior Certificate (NSC - Matric) examinations data from 2008 to 2013 was combined with data from all South African universities (Higher Education Management System (HEMIS) data) from 2009 to 2014 and added to the data from the HEMIS master list and the 20II census. The study found that around a third of those who obtained matric exemption in the 2008 cohort, did not go to university. The authors noted that: "When considering only those matriculants who obtained Bachelor passes (the group considered as potential candidates for university degree programmes), overall university access is not biased against black students...." (Van Broekhuizen et al., 2016, p. i). Furthermore, there were "only small differences in the composition of the two sub-groups of students who achieved Bachelor passes, namely those who do and those who do not access university in the subsequent six years. Only $63.4 \%$ of White matriculants from 2008 who had achieved Bachelor passes went on to study at university in the next six years, as against 71.2\% for Black matriculants with Bachelor passes (Table 7.5)". However, several concerns are noted with regard to this study. We do not offer a complete review of this extensive report, but focus on those aspects relevant to the current study.

A close examination of the figures in some of the authors' tables for sub-group comparisons indicate illogical computations and contradictions, thus casting doubt on their Black vs Whites comparisons. We reproduce parts of Tables 7.5 and 7.3 from their report below. 
Part of Table 7.5. University access, completion, and dropout rate summaries for learners who achieved Bachelor passes in the 2008 NSC, by race group

\begin{tabular}{|l|c|c|c|c|}
\hline & Black & Coloured & Asian & White \\
\hline Share of Bachelor Passes (\%) & 56.4 & 8.2 & 8.0 & 27.4 \\
\hline 6-year access rate & 71.2 & 63.1 & 72.8 & 63.4 \\
\hline - UG degree & 53.7 & 53.3 & 66.1 & 59.0 \\
\hline 1 - Year access rate & 51.3 & 47.5 & 62.9 & 48.7 \\
\hline
\end{tabular}

Source: Van Broekhuizen et al. (2016)

Part of Table 7.3. University access, University access, completion, dropout, and retention rates (\%) for black learners, from the 2008 matric cohort (2009-2014)

\begin{tabular}{|c|c|c|c|c|c|c|}
\hline & 1 year & 2 years & $\begin{array}{c}3 \\
\text { years }\end{array}$ & $\begin{array}{c}4 \\
\text { years }\end{array}$ & 5 years & 6 years \\
\hline & (2009) & (2010) & (2011) & (2012) & $(2013)$ & (2014) \\
\hline \multicolumn{7}{|l|}{ Black learners } \\
\hline Access rate & 9.9 & 13.4 & 14.8 & 15.6 & 16.2 & 16.6 \\
\hline Completion rate & 0.2 & 0.6 & 12.7 & 31.8 & 45.3 & 53.5 \\
\hline Dropout rate & 9.9 & 15.7 & 21 & 26.2 & 32 & - \\
\hline Retention rate & 84.7 & 78.9 & 61.5 & 38.8 & 22.6 & - \\
\hline \multicolumn{7}{|l|}{ White learners } \\
\hline & (2009) & (2010) & (2011) & (2012) & $(2013)$ & (2014) \\
\hline Access rate & 35.5 & 42.5 & 44.8 & 46 & 46.9 & 47.4 \\
\hline Completion rate & o & 0.2 & 24.4 & 52.7 & 65.3 & 71.6 \\
\hline Dropout rate & 6.5 & 10.2 & 13.1 & 15.3 & 18.1 & - \\
\hline Retention rate & 90 & 86.9 & 59.9 & 30.6 & 16.6 & - \\
\hline
\end{tabular}

Source: Van Broekhuizen et al. (2016)

In Table 7.I of Van Broekhuizen et al.'s (2016) report, the authors showed that the percentage of Blacks candidates for the 2008 NSC examinations was $82.5 \%$ while the corresponding percentage for Whites was $7.7 \%$. The same table showed that of the Black candidates, only $13.6 \%$ achieved a Bachelor's pass. The corresponding percentage for Whites was $70.2 \%$. Given that around $80 \%$ of South Africa's population is Black, it is expected that the percentage of Black candidates for the 2008 NSC or any other year would be much higher than the percentage of candidates for the other population groups. This being the case, it is arithmetically illogical for Van Broekhuizen et al. (20I6) to have computed the share of Bachelor's passes as between group percentages in the first row of their Table 7.5, part of which is shown above. Thus, the percentages in the first row of the table are misleading. Secondly, in the second row of their table 7.5, the authors indicate that the six-year access rate for Blacks was $71.2 \%$ while for Whites it was $63.4 \%$. However, Table 7.3 in their report, part of which is reproduced above, indicates that the six-year access rate for Blacks for the 2008 cohort was $16.6 \%$ while the corresponding figure for Whites was $47.4 \%$. The rates in these two tables are contradictory. The seemingly "small differences in the composition of the two sub-groups of students who achieved Bachelor passes, namely those who do and those who do not access university in the subsequent six years" (Van Broekhuizen et al., 20I6 p. ii), was based on the comparison in their Table 7.5. The question is: which table does one believe regarding Black/White university access comparisons in Van Broekhuizen et al.'s (20I6) report?

Furthermore, the multivariate analysis in Van Broekhuizen et al.'s (20I6) study controlled only for matric pass rate and matric average achievement in two different models; yet the authors argued "that racial differentials in university access, completion, conversion, and dropout in South Africa can be explained away almost entirely by differences in matric achievement" (Van Broekhuizen et al., 20I6, p. 78). This statement is inconsistent with the Adjusted $\mathrm{R}^{2}$ values in their multivariate results. The adjusted $\mathrm{R}^{2}$ values for the six-year university access in each of the two multivariate models were 0.415 and 0.392 . Focusing on the higher $\mathrm{R}^{2}$ value indicates that 'race' accounted for a maximum of $4 \mathrm{I} .5 \%$ of the racial differences in the six-year university access. This infers that other factors must be at play. Probable relevant factors include the matriculant's home background or individual socio-economic status. Information on these variables are not available in the Matric examinations or HEMIS data.

Indirect evidence appears to suggest that the tertiary education completion rate might be low. Our computations from the 2016 South Africa's Community Survey unweighted data (Statistics South Africa, 20I6) indicate that $68 \%$ of South Africans aged 25 and over in 2016 had a secondary or higher education qualification. Of these, only about $3.4 \%$ had a Bachelor's degree or higher. When this is decomposed by population group, about $66.3 \%$ of Black South Africans aged 25 and over had a secondary or higher education qualification and of these, $2.4 \%$ had a Bachelor's degree or higher whereas $76.3 \%$ of non-Black South Africans (i.e., Coloured, Indian and White) had a secondary or higher education qualification and of these, $7.9 \%$ had a Bachelor's degree or higher. This study investigated whether transition from secondary to tertiary education is less likely among Black South Africans than their nonBlack counterparts in the democratic dispensation. 


\section{Objectives of the study}

The study's objective was to examine the probability of a specified age cohort transiting to tertiary education in South Africa and to compare Black people with other population groups in transition to tertiary education considering environmental and individual factors. More specifically, the study estimated:

I. The overall probability of South African-born persons aged I8-I9 in 2016 (i.e., one to two years after completing secondary education) transiting to tertiary education.

2. The probability of persons classified as Black aged I8-ig in 2016 transiting to tertiary education in comparison with people classified as Coloureds, Indians/Asians, Whites in the same age group considering environmental and individual factors (confounders).

The research questions arising from the objectives were:

A. What was the probability of a South African-born person aged I8-I9 in 2016 (i.e., after completing secondary school) transiting to tertiary education?

B. Were Black South Africans aged I8-I9 in 2016 less likely to transit to tertiary education than non-Black South Africans of similar age controlling for confounders?

The racial classifications used during apartheid were White, Indian, Coloured (persons of mixed descent), and Black in that hierarchical order. Racial categories in the democratic dispensation are African Black, Coloured, Indian and White (Spaull, 20I3, p. 36) in alphabetical order without hierarchy. While the latter are used in this article, some Coloureds and Indians categorise themselves as Black. This is, however, ideological rather than official statistical classification.

The OECD "follows standard international conventions in using tertiary education to refer to all programmes, regardless of the institutions in which they are offered" (Santiago, Tremblay, Basri, and Arnal, 2008, p. 26). According to the World Bank (20I7), higher education is also known as tertiary education in some countries and it refers to all post-secondary education, including public and private universities, colleges, technical training institutes, and vocational schools. Tertiary education in South Africa is also sometimes referred to as higher education and includes all post-school education offered at various institutions. The mission of the Department of Higher Education and Training (DHET) "is of a South Africa in which we have a differentiated and fully-inclusive post-school system that allows South Africans to access relevant post-school education and training, in order to fulfil the economic and social goals of participation in an inclusive economy and society" (DHET, 2012-202I).
As a background to this study, we present an overview of the apartheid and post-apartheid education system in South Africa.

Overview of the apartheid and post-apartheid education system in South Africa Naicker (2000) notes that, apartheid education promoted race, class, gender and ethnic divisions and emphasised separateness rather than common citizenship and nationhood. It produced a dual system of education which included a mainstream and a special education component that were characterised by racial disparities, with many learners were excluded from the mainstream. Only a small number of Africans graduated from high school (EducationState, 20I3). Chisholm (2012, p. 86) observed that by 1968 , for every 100000 students in a specific population group, 866 Whites, 322 Indians, 74 Coloureds and only I3 Africans were able to reach the final year of schooling.

Racially segregated universities were established in I969 to cater for specific ethnic groups of Black, Indian and Coloured students. Whites had their own universities and the institutions that were established for other population groups were largely under resourced, understaffed, overcrowded and offered limited subjects and qualifications, which reinforced the racial division of labour once students completed their studies (Chisholm, 20I2, p. 88).

South Africa's new Constitution (Republic of South Africa, I996) identified basic education as a right for all citizens and the democratic government that came to power in I994 was committed to ensuring universal education (Chisholm, 20I2, p. 85) . The South African Schools Act (SASA) (Department of Education, I996) provided for compulsory education from the age of seven to I5 or ninth grade.

Since 1994, South African learners have had the choice of three different types of schools: independent or private, public or government, and Model C schools. Public schools depend on the government for funding and material. Private schools, also known as independent schools, are usually owned and operated by a trust, church or community, or by a for-profit company (Schoolguide, 20I8). Model C schools were semi-private structures used to govern Whites-only government schools that were introduced by the apartheid government in 1991. After 1994, they became state-aided (or semi-private). They now admit learners of all races and since they are state-aided, they are regarded as the same as public schools. However, in public discourse, the term 'Model C' is now used to refer to the former Whites-only government schools in South Africa (Christie and McKinney, 20I7).

Public schools, including former Model C schools write the NSC examinations at the end of Grade I2 (Spaull, 20I3, p. 39) that are set by the Department of Basic Education, while private schools write the Independent Examination Board (IEB) exams. Both result in a matric certificate which allows learners entrance to higher education institutions. Depend- 
ing on the level of pass, the learner will have access to certain programmes. For a Bachelor's pass the learner must achieve a minimum of $50 \%$ in four designated 20-credit subjects (excluding Life Orientation) and a minimum of $30 \%$ in three subjects (including Language) (Wedekind, 2013, p. I7).

\section{Data source and study limitations}

Ideally a critical assessment of transition to and completion of tertiary education requires longitudinal cohort data where by those who completed secondary education or registered in tertiary institutions in a specific year are followed over time to examine the proportion that transits to or completes tertiary education after a specified period of years taking into consideration environmental and individual factors. Such data are not publicly available in South Africa. The HEMIS data was noted in the literature review. Some individuals in higher education institutions may have privileged access to such data. The Higher Educational Data Analyser (HEDA) now provides a portal for access to HEMIS data, but these are aggregated data reports (see www.heda.co.za) without no individual student characteristics and are therefore not suitable for the kind of analysis presented in this study that called for anonymised individual unit records. Furthermore, even if available, longitudinal data have inherent limitations including "achievement of the initial sample, sample mortality and conditioning” (Moser and Kalton, I979, p. I40) that cast doubt on the reliability of the results.

In the absence of longitudinal individual unit record data, this study utilised the 2016 South African Community Survey (20I6 CS) - a cross-sectional survey. The target population for the 2016 CS was the noninstitutional population residing in private dwellings (Statistics South Africa, 20I6). The sampling frame was the geo-referenced dwelling frame based on the 20II census enumeration areas (EAs). The final sample consisted of 3328867 persons in 984627 households although Statistics South Africa's (2016) report noted that the final sample for weighting after all the necessary checks and validation consisted of I 422928 households. It should be noted that these data are anonymised unit records and not aggregated data.

The 2016 CS questionnaire included a section on education which consisted of nine questions. Those relevant to this study included the following: I. Is (this person) currently attending an educational institution?

2. Which of the following educational institutions does (this person) attend?

3. What is the highest level of education that (this person) has successfully completed?

The answers to these questions combined with the characteristics of the person available from other parts of the questionnaire were used to achieve the study's objectives. The major limitation is the lack of data on students' performance in the final secondary school examinations. As noted previously, minimum grade levels for subjects in these examinations collectively classified as matric or NSC are required for university admission. Those without matric can pursue other tertiary education such as technical and vocational education and training, or a nursing college, agricultural college, or police college should they wish. In the absence of information in the 2016 CS on the matric pass, it was not possible to determine whether non-transition to university was due to not meeting university admission requirements. Therefore, all post-secondary institutions were combined and labelled tertiary education institutions since a student can pursue tertiary education in a non-university environment without a NSC.

Another limitation of the data relates to employment and income. Although this information was collected in the 2016 CS, Statistics South Africa did not release it in the data files available to the public. Thus, a lack of money to buy food in the household in the past I2 months was used as a proxy for insufficient household income. Finally, due to flaws in the weighting of the data (see Udjo, 20I7), the unweighted data were used.

\section{Methods}

The standard age for completing secondary school in South Africa is I7 or I8. It is therefore expected that, in the absence of social and economic constraints, a secondary school graduate would transit to some form of tertiary education within one to two years of secondary school graduation, i.e., when they are aged I8-I9 irrespective of whether or not they obtained a NSC or matric. Thus, the probability of transiting to tertiary education for a certificate, diploma, or a Bachelor's degree in 2016 can be computed for persons aged i8-I9 as at 2016 whose highest level of education was Grade I2. The study focused on South African-born persons living in the country disaggregated by population group to avoid external 'contamination' of environmental and individual factors. The circumstances of foreign-born persons who migrated to South Africa may be different from those of South African-born persons living in the country. The advantage of focusing on one to two years after secondary school graduation for persons aged i8-I9, is that it is unlikely that the environmental and individual factors may have changed much. It should be noted that students that started school later or those that took longer to complete matric were not included in this study.

The analysis involved univariate and bi-variate descriptive statistical methods followed by logistic multivariate analysis. The logistic regression involved several models. In terms of the first objective, the overall probability of a South African-born person aged I8-19 in 2016 transiting to 
tertiary education was estimated. Thereafter, each factor associated with the probability of a South African-born person aged I8-I9 in 2016 transiting to tertiary education (dependent variable) was examined in a bi-variate logistic regression. The statistically significant factors resulting from this model were noted. In the next stage, the probability of a Black South African-born person aged I8-I9 in 2016 transiting to tertiary education (dependent variable) compared with each of the other population groups of similar age (independent variable) was estimated without controlling for confounders. Finally, the probability of a specified population group transiting to tertiary education was estimated controlling for confounders. Because the circumstances of each of the population groups are not necessarily the same, non-Black South Africans were not lumped together as a single category; instead, Black South Africans were used as reference group for comparison with each of the other population groups.

The selection of the confounders was based on the literature review presented earlier. The review revealed that some of the factors associated with university non-completion are similar to those associated with transition to tertiary education. Temporal effects may sometimes be at play. In view of this and due to data limitations, the dependent, independent and confounders examined in this study were as follows. To avoid repetition, the citations are indicated after each variable without repeating the link between the variable and transition to tertiary education since the link was provided in the literature review.

\section{Dependent variable}

Transition to tertiary education.

\section{Independent variable}

Population group: Black South Africans compared with each of the other non-Black South African population groups (see Harper (2012) above).

\section{Confounders}

Household/Environmental factors: Ran out of money to buy food in the household in the past I2 months (as a proxy for insufficient income in the household); educational level of house head (household head as a proxy for parent) (see Weiss and Steininger (20I2) above); age of household head (household head as a proxy for parent) (see Schieferdecker and Riphahn (20I2) above).

Individual factors: sex of student (see Salmi and Basset (20I4) above), parental survival (father/mother alive). A parent's death has an effect on a child's enrolment and reduces the probability of acquiring higher education (Gertler et al., 2004; Gimenez et al., 2013).

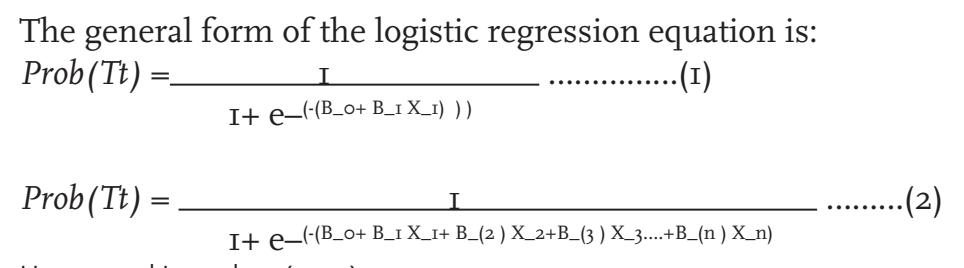

Hosmer and Lemeshaw (2000).

Equation (I) is a bi-variate logistic regression. It assessed the relationship between transition to tertiary education (dependent variable) and belonging to a specific population group (independent variable). Equation (2) assessed the same relationship as equation (I), but included confounders. The variables in the equations were defined as follows:

\section{Dependent variable}

Prob (Tt) is the probability of a South African-born person living in South Africa aged I8-I9 in 20I6 that had at least Grade I2 transiting to tertiary education (Tt).

$T t=\mathrm{I}$ if a South African-born person living in South Africa aged I8-I9 in 2016 had at least Grade I2 and was attending tertiary education in 20I6;

$T t=0$ if a South African-born person living in South Africa aged I8-I9 in 2016 had at least Grade I2 and was not attending tertiary education in 2016;

$e=$ base of the natural logarithm;

$\beta_{O}=$ constant;

$\beta_{1} . . n=$ estimated coefficients corresponding to the covariates $\mathrm{XI}_{\mathrm{I}} \ldots \mathrm{Xn}$

Independent Variable

$X_{1}=$ Population group (Indicator variable): $\mathrm{I}=$ Black (reference group), $\mathrm{o}$ for each of the other population groups.

\section{Confounders}

Household/Environmental factors

$X_{2}=$ Ran out of money to buy food in the household in the past twelve months: 1 = Ran out of money.

$\mathrm{O}=$ Did not run out of money (reference group).

$X_{3}=$ Educational level of household head (Indicator variable): $\mathrm{I}=$ Lower than tertiary level or no education (reference group), o for each of the other educational levels (tertiary, higher than tertiary).

$X_{4}=$ Age of household head (Indicator variable): $\mathrm{I}=20-34$ years (reference group) $\circ$ for each of the other age groups (IO-I9 years, 35 years and over). 


\section{Individual factors}

$X=$ Sex: $\mathrm{I}=$ male, $\mathrm{O}=$ female (reference group).

$X_{6}=$ Mother alive: $\mathrm{I}=$ Yes, $\mathrm{O}=$ No (reference group).

$X_{7}=$ Father alive: $\mathrm{I}=$ Yes, $\mathrm{O}=$ No (reference group).

$X_{8}=$ Mother and father alive: $\mathrm{I}=$ Yes, $\mathrm{O}=$ No (reference group).

\section{Results}

Background Characteristics

Table I shows that of the South African-born persons living in South Africa aged I8-I9 in 2016 who had at least Grade I2, 36\% were in tertiary education institutions, about $82 \%$ were Black, $4 \mathrm{I} \%$ were female and $87 \%$ had a surviving mother. As a proxy for income, about $79 \%$ of this group indicated that they did not run out of money in their household to buy food in the past I2 months.

Table 1: Characteristics of South African-born persons living in South Africa aged 18-19 in 2016 with at least a Matric $(n=32904)$

\begin{tabular}{|l|c|}
\hline Variable & Percent \\
\hline 1. Current Type of Educational Institution & 2.0 \\
\hline Non-tertiary & 36. \\
\hline Tertiary & 62.0 \\
\hline Unknown/Not applicable & 81.6 \\
\hline 2. Population Group & 10.0 \\
\hline Black & 3.0 \\
\hline Coloured & 5.4 \\
\hline Indian/Asian & \\
\hline White & 41.4 \\
\hline 3. Sex & 58.6 \\
\hline Male & \\
\hline Female & 9.0 \\
\hline 4. Age of Household Head (yrs) & 10.0 \\
\hline 10-19 & 81.0 \\
\hline 20-34 & \multicolumn{2}{|l|}{} \\
\hline 35+ & 7.3 \\
\hline 5. Highest Educational Level of Household Head & 0.7 \\
\hline Grade 12 & 92.0 \\
\hline Higher than Grade 12 & \\
\hline Unknown & 20.4 \\
\hline 6. Ran Out of Money to Buy Food in past 12 Months \\
\hline Yes & 79.2 \\
\hline No & 0.4 \\
\hline Unknown & 87.6 \\
\hline 7. Biological Mother Alive & \multicolumn{2}{|l|}{} \\
\hline Yes & \\
\hline \multicolumn{2}{|l}{} \\
\hline
\end{tabular}

\begin{tabular}{|l|c|}
\hline Variable & Percent \\
\hline No & 11.6 \\
\hline Unknown & 0.7 \\
\hline 8. Biological Father Alive & \\
\hline Yes & 75.3 \\
\hline No & 19.0 \\
\hline Unknown & 5.8 \\
\hline
\end{tabular}

Source: Authors' computation from 2016 CS

Uni-variate and Bi-variate Results: Independent Effects of Household, Environmental and Individual Factors on Transition to Tertiary Education

The results indicate that the overall probability of South African-born persons aged I8-I9 in 20I6 transiting to any tertiary education institution in 2016 was 0.36 . However, among this group the probability of transiting to a higher education institution including university was only 0.08 in 20I6. The bi-variate logistic regression analysis regressed each household/ environmental and individual factor with tertiary education transition, i.e., without controlling for confounders. The results that are summarised in Table 2 indicate that poverty (measured by a proxy variable - ran out of money to buy food in the past I2 months) had a significant negative effect on transition to tertiary education among persons aged I8-I9 in 2016 who had at least Grade 12 ( $<<0.008)$. Furthermore, among this group, the mother being alive had a significant positive effect on transition to higher education $(\mathrm{p}<\mathrm{0.00I})$. There was no statistically significant difference between males and females as well as in the age of the head of the household among this group in terms of transition to tertiary education $(\mathrm{p}>0.05)$.

Table 2: Bi-variate Logistic Regression Showing the Relationship of Household/Environmenta and Individual Factors with Transition to Tertiary Education among South African-Born Persons Aged 18-19 with at least Grade 12 in $2016(n=32$ 904)

\begin{tabular}{|l|c|c|c|}
\hline Transition to tertiary education & Coefficient & $\begin{array}{l}\text { Standard } \\
\text { Error }\end{array}$ & Significance \\
\hline Household/Environmental & -0.269 & 0.101 & 0.008 \\
\hline Ran out of money for food in the past 12 months & -0.010 & 0.418 & 0.981 \\
\hline Household head's education level & 0.257 & 0.187 & 0.170 \\
\hline Household Head's age group 10-19 & -0.223 & 0.138 & 0.106 \\
\hline Household Head's age group 35 and over & 0.054 & 0.081 & 0.504 \\
\hline Individual Factors & 0.390 & 0.120 & 0.001 \\
\hline Sex & 0.053 & 0.108 & 0.625 \\
\hline Mother alive & 0.141 & 0.096 & 0.143 \\
\hline Father alive & & & \\
\hline Mother and father alive &
\end{tabular}

Source: Authors' computation from 2016 CS 


\section{Multivariate Results}

The significant variables noted in the bi-variate results were included in a multivariate analysis that examined the relationship between transition to higher education and belonging to a specific population group controlling for household, environmental and individual factors. The overall results of the multivariate analysis are summarised in Table 3.

Table 3: Logistic Regression of Transition to Tertiary Education by Population Group and Confounders among South African-Born Persons Aged 18-19 who had at least Grade 12 in $2016(n=32$ 904)

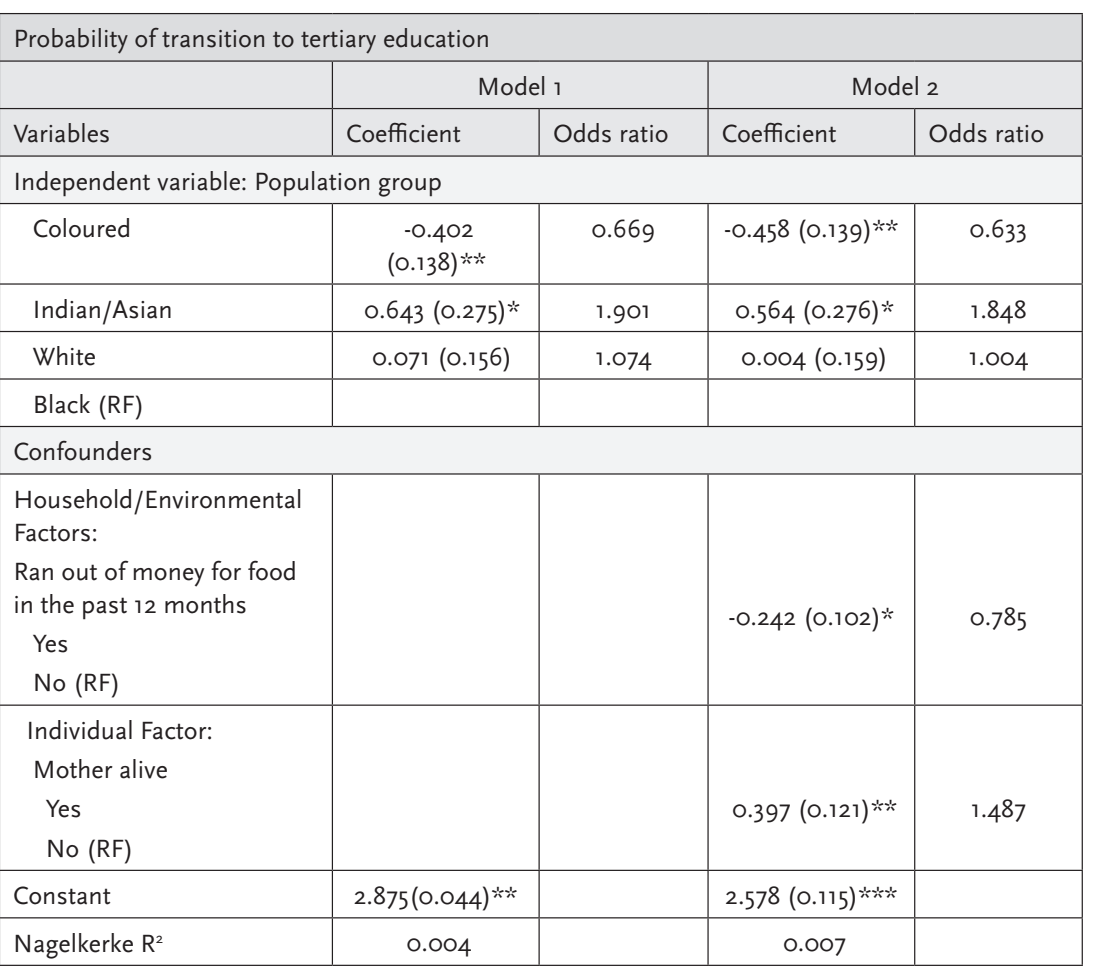

$\mathrm{RF}=$ Reference category, standard errors in parenthesis.

*Statistically significant $p<0.05$.

$* *$ Statistically significant $p<0.001$

$*$ * ${ }^{2}$ Statistically significant $p<0.000$

Source: Authors' computation from 2016 CS

Model I in the table does not control for confounders.
After controlling for confounders (household, environmental and individual factors) in Model 2, the results indicate that the odds of transiting to tertiary education among Whites aged I8-I9 who had at least Grade I2 were similar to that of Blacks of similar age and educational level in 20I6. The difference between the two groups after controlling for the above-mentioned confounders was only 0.004 and was not statistically significant (p>0.05). Comparing Blacks with Coloureds and controlling for the above-mentioned confounders, Model 2 shows that the odds of transiting to tertiary education among those aged I8-I9 with at least Grade I2 in 2016 were less for Coloureds by about $37 \%$. This difference is statistically significant $(\mathrm{p}<0.00 \mathrm{I})$. Model 2 further shows that comparing Indians/Asians with Blacks in the specified age group and controlling for the above-mentioned confounders Indians/Asians were about I. 8 times more likely than Blacks to transit to tertiary education in 20I6. The difference is statistically significant $(\mathrm{p}<0.00 \mathrm{I})$.

Other aspects of the results in Model 2 in Table 3 indicate that controlling for population group and other variables, persons aged I8-I9 with at least Grade 12 who lived in poor households were significantly less likely to transit to tertiary education than persons aged I8-I9 with at least a Grade I2 who did not live in poor households in 2016 (p<0.0I8). Furthermore, controlling for the above-mentioned confounders, persons aged I8-I9 who had at least a Grade I2 in 2016 and whose mothers were alive were significantly more likely to transit to tertiary education than persons of similar age and education level whose mothers were dead (p<0.00I).

\section{Discussion and conclusion}

An ideal comparison of population groups' tertiary education completion rates in South Africa would involve the use of longitudinal (panel) data in which a cohort of students of different population groups are followed over time and which include the household, environmental and individual characteristics of the cohort of students that enrolled at the start of the follow up. The analysis would normally involve the use of life table methods (in a demographic sense). Such data are currently not publicly available in South Africa. In its absence, this study utilised cross-sectional data on persons in different population groups aged I8-I9 in 2016 who had a matric transiting to tertiary education considering environmental and individual factors. We noted that even if longitudinal data were available, such data suffer from inherent problems.

The weaknesses in our analysis primarily arise from the limitations of the data utilised. The data did not include information on whether the persons of interest in the analysis obtained a matric pass. This is an important factor in transition to university education. To address this limitation, this study focused on the probability of transiting to a tertiary institution and not neces- 
sarily transition to university. All persons with Grade I2 are qualified to transit to at least the lowest level (i.e., certificate) of tertiary education. Household or individual income - an important factor in pursuing tertiary education - was not available in the data. We therefore used a proxy measure - ran out of money in the household to buy food in the past I2 months.

Despite these limitations, our results indicate that the overall probability of South African-born persons aged I8-I9 in 2016 transiting to any tertiary education was low (36\%). This suggests that certain factors inhibited them from doing so.

Controlling for confounders, the study did not find evidence that transition from secondary to tertiary education among persons aged I8-i9 in 2016 who had at least Grade I2 was significantly less likely among South Africanborn Black people than among South African-born Whites of similar age. However, controlling for confounders, Indians/Asians aged I8-I9 who had at least Grade I2 were significantly more likely to transit to tertiary education in 2016 than Black people of similar age and level of education. These findings are relevant to guide policy formulation to improve the quality of the labour market and thus the country's economic competitiveness. We recommend that the HEMIS individual level anonymised data be made publicly available to enrich future research on transition to tertiary education.

\section{References}

Blondal S., Field S., and Girouard N. (2002). Investment in human capital through upper-secondary and tertiary education. OECD Economic Studies 34, 4I-89.

Chisholm, L. (20I2). Apartheid Education Legacies and new Directions in Post-Apartheid South Africa. Storia delle Donne 8(20I2), 8I-IO3. Available at: https://www.researchgate.net/publication/234II55I7. (Accessed 2 September 20I9).

Christie, P., and McKinney, C. (2OI7). Decoloniality and "Model C" Schools: Ethos, Language and the Protests of 2016. Education as Change 21(3), I-2I. Available at: http://dx.doi.org/IO.I7I59/I947-94I7/20I7/2332.

Department of Education. (I996). South African Schools Act (SASA) (Act 84 of I996). Pretoria: Government Printer.

DHET. (2012-202I). Department of Higher Education and Training. Available at: https://nationalgovernment.co.za/units/view/I7/department-ofhigher-education-and-training-dhet (Accessed I February 202I).

EducationState. (2013). Nelson Mandela on Education: The Bantu Education Act I953 and Its Consequences. Available at: http://www. educationstate.org/2013/12/06/nelson-mandela-education-bantueducation-act-r953-consequences/. (Accessed 2 September 20I9).

Essack, S.Y. (2OI2). Translating equitable access into retention and success in African higher education: the role and responsibility of individual institutions. Journal of Higher Education in Africa 10(2), 47-62.

Gertler, P., Levine, P., and Ames, M. (2004). Schooling and parental death. The Review of Economics and Statistics 86(I), 2II-225.

Gimenez, L., Chou, S.Y., Liu, J.T., and Liu, J.L. (2013). Parental loss and children's well-being. The Journal of Human Resources, 48(4), I035-I07I.

Harper, S.R. (20I2). Black male student success in higher education: a report from the National Black Male College Achievement Study. Philadelphia: University of Pennsylvania, Center for the Study of Race and Equity Education. Available at: www.works.bepress.com/sharper/43. (Accessed 2 September 20I9).

HEDA. (2020). Higher Education Data Analyser Portal. Available at: http://www. heda.co.za/indicatordashboard/default.aspx. (Accessed 6 July 2020).

Higher Education South Africa (HESA). (20I4). South African Higher Education in the 2oth Year of Democracy: Context, Achievements and Key Challenges. HESA presentation to the Portfolio Committee on Higher Education and Training, Cape Town, 5 March. Available at http://pmg-assets.s3-website-eu-west-I.amazonaws.com/I40305hesa. pdf. (Accessed 2i September 2019).

Hobden, S., and Hobden, P. (20I5). A study of the transition pathways of school level scholarship recipients into work and tertiary education. South African Journal of Education 35(3), I-IO. http://dx.doi. org/IO.I5700/SAJE.V35N3Aio54.

Hosmer, D.W., and Lemeshow, S. (2000). Applied logistic regression. New York: John Wiley and Sons.

Lamb, S., and Markussen, E. (20II). School dropout and completion: an international perspective. In: Lamb, S., Markussen, E., Teese, R., Polesel, J., and Sandberg. N. (eds) School dropout and Completion, pp. I-8. Dordrecht: Springer.

Matkovic, T., and Kogan, I. (20I2). All or nothing? The consequences of tertiary education non-completion in Croatia and Serbia. European Sociological Review 28(6), 755-770.

Moser, C.A. and Kalton, G. (I979). Survey methods in social investigation. London: Heinemann Educational Books.

Naicker, S.M. (2000). From apartheid education to inclusive education: The challenges of transformation. International Education Summit for a Democratic Society, Wayne State University, Detroit, Michigan U.S.A. June 26-28, 2000.

O'Koeffe, P. (20I3). A sense of belonging: Improving student retention. College Student Journal 47(4), 605-613.

Owens, J. (2004). A review of the social and non-market returns to education. Wales, UK: Education and learning network. 
Patterson, A. (2013). The top ro Nelson Mandela quotes on education. Available at: https://writerswrite.co.za/rest-in-peace-nelson-mandela/ (Accessed 5 January 20I8).

Raborife, M. (2OI7). Black students will continue to drop out without support - Lehohle. Available at: https://www.news24.com/SouthAfrica/ News/black-students-will-continue-to-drop-out-without-support-lehohle-20I70I23. (Accessed 28 August 2019).

Radford, A.W., Wheeless, S.C., and Hunt-White, T. (2010). Persistence and attainment of 2003-04 beginning postsecondary students: after 6 years. Institute of Education Sciences, National Centre for Education Statistics.

Republic of South Africa. (I996). Constitution of the Republic of South Africa, Act 108 of 1996. Pretoria: Government Printer.

Salmi, J. and Bassett, R.M. (20I4). The equity imperative in tertiary education: promoting fairness and efficiency. International Review of Education 6o(3), 36I-377.

Santiago, P., Tremblay, K., Basri, E., and Arnal, E. (2008). Tertiary Education for the knowledge society - Volume 1: Special features: Governance, funding, quality. Paris: OECD Publishing.

Schieferdecker, F., and Riphahn, R.T. (20I2). The transition to tertiary education and parental background over time. Journal of Population Economics 25(2), 635-675.

Schoolguide. (2018). Public, Private or Model C: which school is best? Available at: https://www.schoolguide.co.za/guide/primary/entry/ primary/public-vs-private-which-school-is-best.html. (Accessed I7 September 20I9).

Scott, D. (2005). Retention, completion and progression in tertiary education in New Zealand. Journal of Higher Education Policy and Management 27(I), 3-I7.

Shapiro, D., Dundar, A., Wakhungu, P.K., Yuan, X., Nathan, A., and Hwang, Y. (2OI5). Completing College: A National View of Student Attainment Rates - Fall 2009 Cohort (Signature Report No. Io). Herndon, VA: National Student Clearinghouse Research Center.

Spaull, N. (20I3). Poverty and privilege: Primary school inequality in South Africa. International Journal of Educational Development 33(2013), 436447.

Statistics South Africa. (2016). Community Survey 2016 Technical Report. Pretoria: Statistics South Africa.

Udjo, E.O. (20I7). Evaluating the demographic aspects and estimating demographic indicators from the 2016 South Africa Community Survey. Pretoria: Bureau of Market Research Report No. 486.

Van Broekhuizen, H., Van Der Berg, S., and Hofmeyr, H. (20I6). Higher education access and outcomes for the 2008 matric cohort. Stellenbosch Economic Working Papers: I6/16.

Vandenberghe, V. (2007). Family income and tertiary education attendance across the EU: an empirical assessment using sibling data. LSE STICERD Research Paper No. CASE I23.

Wedekind, V. (2013). NSC Pass Requirements: A discussion document for Umalusi on the NSC Pass mark. Pretoria: UMALUSI, Council for Quality Assurance in General and Further Education and Training.

Weiss, F. and Steininger, H. (20I2). Educational family background and the realisation of educational career intentions: participation of German upper secondary graduates in higher education over time. Higher Education 66(2), 189-202.

World Bank (20I7). Understanding poverty: Higher education. Available at: https://www.worldbank.org/en/topic/tertiaryeducation. (Accessed I February 202I).

Yorke, M. (1998). Non-completion of undergraduate study: some implications for policy in higher education. Journal of Higher Education Policy and Management 20(2), I89-201. 